Vol. 23, No. 4, pp. 430 438, 2020.

\title{
Plasma-Engineered Silica Acid Catalysts for Coffee Waste Conversion to Xylose
}

\author{
Sungho Lee, Qin Lusha, Oi Lun Li ${ }^{\dagger}$
}

School of Materials Science and Engineering, Pusan National University,

2 Busandaehak-ro 63beon-gil, Jangjeon 2(I)-dong, Geumjeong-gu, Busan 46241, Republic of Korea

\section{플라즈마 공법으로 제조된 실리카 산촉매를 이용한 커피찌꺼기의 자일로스로의 전환}

\author{
이성호, 친루사, 리오이룬 ${ }^{\dagger}$ \\ 부산대학교 재료공학과
}

(Received November 16 2020; Revised December 9 2020; Accepted December 10 2020)

\begin{abstract}
s
Recently, the need for next-generation energy sources to replace fossil energy is increasing rapidly due to various problems such as depletion of oil and generation of carbon dioxide. One alternative to this is coffee grounds, one of the substances being studied. Coffee is consumed a lot around the world, but the disposal of the grounds is a big problem. However, this coffee grounds can be used as a raw material for biodiesel because it is made of various organic compounds such as cellulose and hemicellulose. The most common process to make biodiesel is the process using concentrated sulfuric acid as homogeneous catalysts to break down coffee into monosaccharides. However, the corrosive nature and disposal problem create environmental concerns in this process. Recently, heterogeneous silica acid catalyst, attracts many attention due to its environmental friendly nature, low cost and recyclability. In this experiment, instead of the sol-gel method for preparing a conventional silica acid catalyst, we prepared silica acid catalyst using a plasma method that can improve the catalytic performance. In the case of using the plasma method, the specific surface area increased and the catalyst performance increased, which led to an increase in xylose conversion and selectivity of $6 \%$ and $4 \%$, respectively.
\end{abstract}

Keywords: solution plasma, silica, acid catalyst, silica catalyst, plasma

${ }^{\dagger}$ Corresponding Author: Oi Lun Li

E-mail: helenali@pusan.ac.kr 


\section{1. 서론}

실리카는 대표적인 무기재료로, 열적 성질과 기계적 강도 향상에 효과적이고 낮은 유전상수를 가지는 특성 을 가지고 있어 촉매, 전자재료 등에 적용되고 있다. ${ }^{1}$ 실 리카는 전자부품, 기계재료, 화학촉매 등 여러 분야에 널리 사용되고 있는 재료 중 하나이다. 일반적으로 실리 카는 졸-겔법을 이용하여 제조된다. 이 방법을 이용할 경우 미크론 급의 크기로 균일한 실리카 구형분말을 제 조할 수 있고, 상온에서 제조가 가능하기 때문에 널리 쓰이고 있다 ${ }^{2)}$. 그러나 촉매의 경우 미크론 단위로는 촉 매의 성능을 충분히 발휘하기 어렵기 때문에 더 작은 규 모의 실리카 제조가 필요하다. TEOS와 암모니아의 비 율에 따라 실리카의 지름이 달라진다는 연구에 따라. 암 모니아를 실리카 합성에서의 촉매로 사용하였다. ${ }^{3)}$ 최근 설폰화 탄소, 설폰화 실리카, 설폰화 제올라이트와 같이 다양한 종류의 불균일 촉매들이 연구중에 있다 ${ }^{4-7)}$. 이들 대부분은 나노 단위의 구조를 가지며 특히 메조포러스 (mesoporous) 실리카는 불균일 촉매의 가능성을 크게 확장시켰다. 이러한 메조포러스 실리카의 큰 기공은 다 양한 재료에 의해 선택적으로 촉매의 제조가 가능하기 때문에 촉매에서 널리 쓰이고 있당)

이러한 점에 착안하여 이 실험에서는 더 뛰어난 성능 의 실리카를 제조하기 위해 플라즈마 공법을 이용할 예 정이다. 플라즈마를 이용하여 실리카를 제조할 경우 더 짧은 시간에 실리카를 제조할 수 있을 뿐 아니라, 크기 가 더 작고 기공이 많은 실리카를 제조가 가능하다. 이 러한 장점으로 인해 플라즈마를 이용해 만든 실리카는 촉매로서의 더 좋은 성능이 기대된다.

촉매의 성능을 평가하기 위해서 커피 찌꺼기를 분해 할 것이다. 최근 전세계적으로 커피의 생산량과 소비량 이 증가함에 따라 커피 찌꺼기의 처리 역시 큰 사회적 문제로 대두되고 있다. 한국인의 경우 커피 수입시장은 2014년 기준 5.9억 달러로, 성인 1인당 커피 소비량은 341잔 수준으로 조사되었다. ${ }^{9}$ 커피 소비량은 해가 지날 수록 증가하는 추세로, 커피 한잔을 추출하고 나면 대부 분의 커피 찌꺼기는 그대로 쓰레기로 처리해야 하는데, 경제적 환경적으로 큰 문제가 된다. 커피 찌꺼기는 셀룰
로오스(Cellulose), 헤미셀룰로오스(hemicellulose), 지 방산과 같은 유기화합물로 이루어져있다. 특히 셀룰로 오스와 헤미셀룰로오스를 가수분해하면 육탄당의 글루 코스(Glucose)와 오탄당의 자일로스(Xylose)라는 단당 류로 분해가 가능하다. 생성된 단당류를 이용하여 에탄 올의 생성이 가능하기 때문에 석유를 대체 할 수 있는 새로운 친환경 에너지 재료, 즉 바이오디젤의 재료로 각 광 받고 있다. ${ }^{10)}$

이 실험에서는 플라즈마를 이용하여 만든 실리카 산촉 매를 통해 커피 찌꺼기를 분해하여 바이오디젤의 생산 을 위한 단당류를 생성할 것이다. 플라즈마 공법을 통해 뛰어난 성능의 촉매를 생산하여, 커피 찌꺼기의 효율적 인 분해가 가능해지면, 전 세계적으로 문제가 되고 있는 환경 문제를 해결하는데 큰 기여를 할 수 있을 것이다.

\section{2. 본론}

\section{1 실리카 제조}

\subsection{1 재료}

나노 크기의 실리카를 제조하기 위해서 필요한 재료 들은 다음과 같다. 주재료인 Tetraethyl orthosilicate (TESOS 95\%)와 암모니아 수용액 (Ammonia solution, $\left.\mathrm{NH}_{4} \mathrm{OH} 30 \%\right)$ 은 $\mathrm{SAMCHUN}$ 의 시약을 사용하였고, 에 탄올 (Ethyl alcohol, $\mathrm{C}_{2} \mathrm{H}_{5} \mathrm{OH}$ 99.9\%)는 DUKSAN에서 구매하였다. 이 재료들에 대한 구조는 Fig 1에 나타내었 다. 이 시약들을 기존 졸-겔법과 플라즈마 공법 모두 다 음과 같은 비율로 실험을 진행하였다.

TEOS : $\mathrm{NH}_{4} \mathrm{OH}: \mathrm{C}_{2} \mathrm{H}_{5} \mathrm{OH}=1: 10: 20$

\subsubsection{Sol-Gel 반응}

졸-겔법은 금속의 유기 및 무기화합물의 용액을 겔 화시키고 겔의 열처리를 통하여 산화물 고체를 제조하 는 방법으로 분자단위의 구조를 조절할 수 있는 초미세 구조공정(ultra structure processing)을 통하여 분말 이나 섬유, 박막 및 겔 모노리스(monolith)등의 제조가 가능하여 여러 분야에 쓰이고 있는 방법이다. 졸-겔법 
<smiles>CCO[Si](OCC)(OCC)OCC</smiles>

TEOS

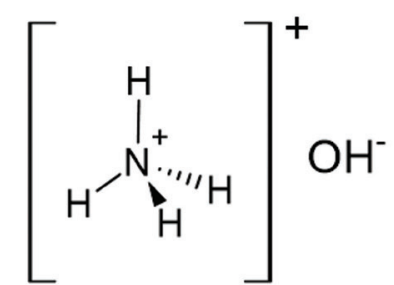

$\mathrm{NH}_{4} \mathrm{OH}$<smiles>CCO</smiles>

$\mathrm{C}_{2} \mathrm{H}_{5} \mathrm{OH}$

Fig 1. TEOS, $\mathrm{NH}_{4} \mathrm{OH}, \mathrm{C}_{2} \mathrm{H}_{5} \mathrm{OH}$ 의 분자구조

에 의한 무기재료 합성의 역사는 1946년부터 시작하여 1959년에 독일의 Shott사에서 금속 알콕사이드를 이용 하여 $\mathrm{SiO}_{2}$ 막 등을 판유리에 형성시키는 연구로 본격화 되기 시작했다1).

실리카를 합성하는 기본적인 졸-겔법은 다음과 같은 가수분해 반응을 따른다.

$\mathrm{Si}\left(\mathrm{OC}_{2} \mathrm{H}_{5}\right)_{4}+\mathrm{xH}_{2} \mathrm{O} \rightarrow \mathrm{Si}\left(\mathrm{OC}_{2} \mathrm{H}_{5}\right)_{4}-\mathrm{x}(\mathrm{OH})_{\mathrm{x}}+\mathrm{xC}_{2} \mathrm{H}_{5} \mathrm{OH}$ $\equiv \mathrm{Si}-\mathrm{OC}_{2} \mathrm{H}_{5}+\mathrm{HO}-\mathrm{Si} \equiv \rightarrow \equiv \mathrm{Si}-\mathrm{O}-\mathrm{Si} \equiv+\mathrm{C}_{2} \mathrm{H}_{5} \mathrm{OH}$ $\equiv \mathrm{Si}-\mathrm{OH}+\mathrm{HO}-\mathrm{Si} \equiv \rightarrow \equiv \mathrm{Si}-\mathrm{O}-\mathrm{Si} \equiv+\mathrm{H}_{2} \mathrm{O}$

전체적인 반응식을 정리하면 다음과 같다.

$\mathrm{Si}\left(\mathrm{OC}_{2} \mathrm{H}_{5}\right)_{4}+2 \mathrm{H}_{2} \mathrm{O} \rightarrow \mathrm{SiO}_{2}+4 \mathrm{C}_{2} \mathrm{H}_{5} \mathrm{OH}$

앞서 2.1.2에서 말했던 TEOS : $\mathrm{NH}_{4} \mathrm{OH}: \mathrm{C}_{2} \mathrm{H}_{5} \mathrm{OH}=$ $1: 10: 20$ 의 비율로 30 분간 합성을 진행하였다. 이후 $80^{\circ} \mathrm{C}$ 오븐에서 24 시간 동안 건조하였고, 수득량을 측정 하였다.

\subsection{3 플라즈마공법}

플라즈마로 실리카를 제조하기 위해 자체 제작한 비 커에 텅스텐 전극을 통해 전류를 흘러 주었다. 이에 대 한 대략적인 그림은 Fig 2와 같다. 전압기로부터 가해진 전류가 텅스텐 전극을 통해 용액 내에서 플라즈마 반응 을 일으키고, 플라즈마 주변부에 고온을 비롯한 추가적 인 에너지의 공급 분위기가 생겨 기존 졸-겔법과 다른 방법으로 실리카의 합성이 가능하다. 졸-겔법과 동일한 조건으로 30 분의 합성 시간과 $80^{\circ} \mathrm{C}$ 오븐에서 24 시간 동

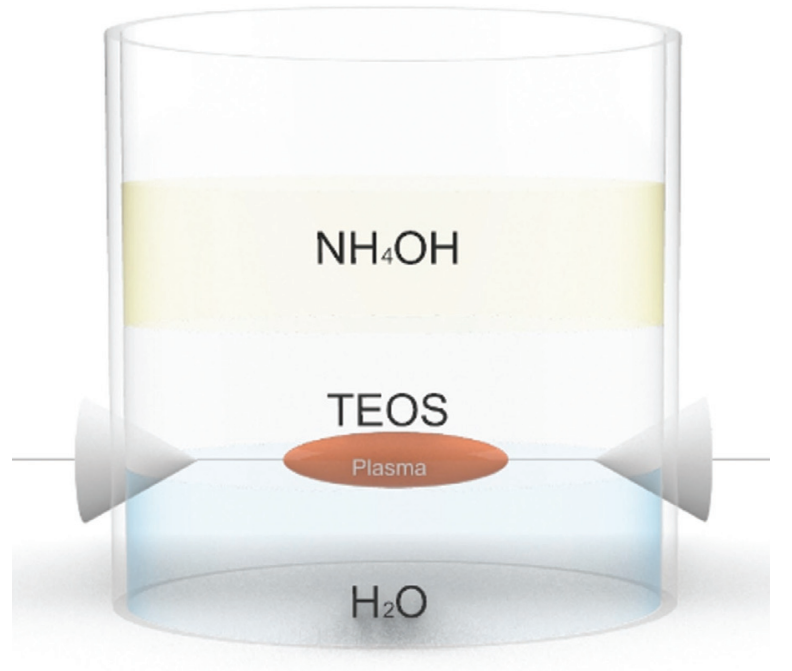

Fig 2. 플라즈마공법을 이용한 실리카 제조의 그림

안 건조 후 수득량을 측정하였다. 플라즈마를 이용하여 합성하는 경우 플라즈마에 의한 고열이 발생하기 때문 에, 상온에서 실험을 진행한 졸-겔법과 동일한 조건을 맞추기 위하여 온도를 측정하며 플라즈마와 냉각을 번 갈아 진행하며 실험하였다.

\subsection{4 실리카 수득량 비교}

수득량의 평균을 아래 Table 1 에 나타내었다. 같은 시간, 같은 조건에서 생성했음에도 불구하고, 플라즈마 를 이용하였을 때 약 1.5 배의 수득률을 보였다. 이 결과 를 통해 봤을 때, 플라즈마 공법을 이용할 경우 더 많은 양의 실리카를 생산할 수 있음을 알 수 있다. 
Table 1. 실리카 제조 방법간 수득량 비교

\begin{tabular}{c|c|c}
\hline & 무게 & 비고 \\
\hline 졸-겔법 & $413 \mathrm{mg} \pm 10 \mathrm{mg}$ & \\
\hline 플라즈마공법 & $622 \mathrm{mg} \pm 5 \mathrm{mg}$ & 약 1.5 배의 높은 수득률 \\
\hline
\end{tabular}

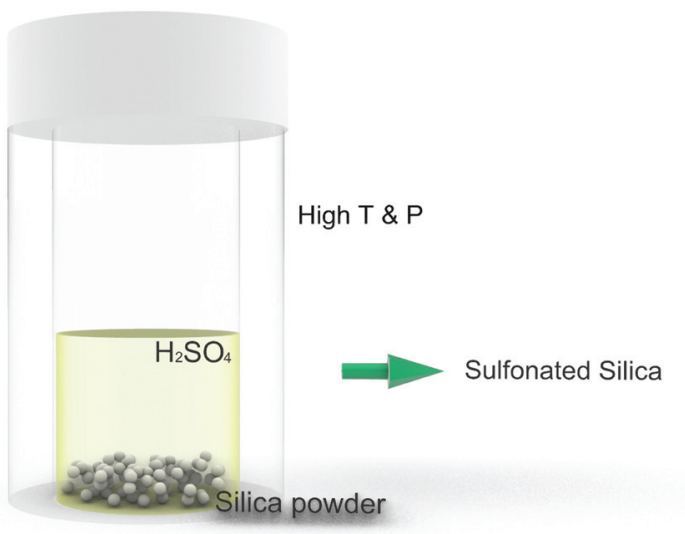

Fig 3. 황산을 이용한 산촉매 제조

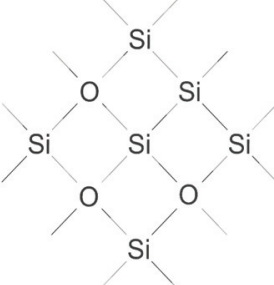

Silica

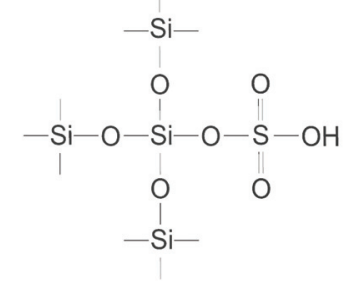

Sulfonated Silica
Fig 4. 실리카와 설폰화 실리카 촉매 구조

\section{2 산촉매 제조, 설폰화 반응}

산촉매를 제조하는 일반적인 방법으로는 화합물에 황 산 $\left(\mathrm{H}_{2} \mathrm{SO}_{4}\right)$ 을 이용하여 황산에 있는 설폰기 $\left(-\mathrm{SO}_{3} \mathrm{H}\right)$ 를 도입하여 설폰산을 생성한다. 이때 사용하는 황산으로 는 진한 황산 $(99 \%)$ 를 사용한다. 설폰산 촉매는 설폰산 작용기 $\left(\mathrm{SO}_{3} \mathrm{H}\right)$ 와 카르복실기 $(-\mathrm{OH})$ 를 표면에 포함하 고 있다 ${ }^{12)}$. 이 작용기들로 커피 분자의 탄소 결합을 끊어 단당류의 생산이 가능하다. 이 실험을 위해서 수열합성 기에 $50 \mathrm{mg}$ 의 실리카와 $5 \mathrm{ml}$ 의 진한 황산을 첨가하였다. 수열 합성기에서의 반응은 Fig 3에서 나타내었다. 이후 $180^{\circ} \mathrm{C}$ 의 오븐에서 18 시간을 반응시킨 후 충분히 냉각시

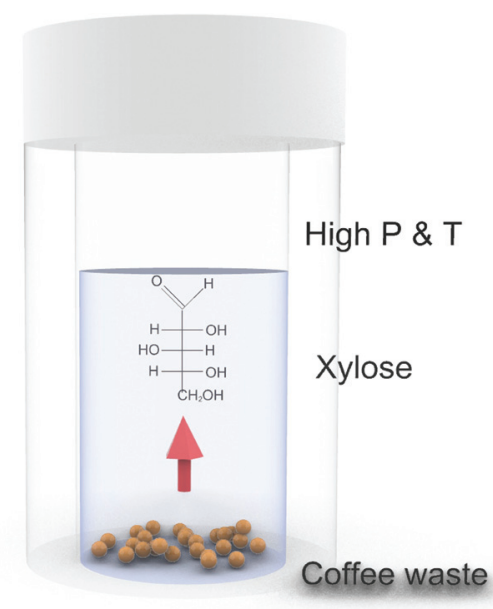

Fig 5. 커피와 산촉매의 가수분해 반응

킨다. 상온과 비슷한 온도가 되면, 여과장치에 황산을 걸러낸다. 걸러내고 남은 촉매는 황산을 완전히 없애주 기 위해 $80^{\circ} \mathrm{C}$ 의 증류수에서 2 시간 더 세척하고 다시 한 번 여과장치로 걸러낸다. 이 과정이 끝나면 $80^{\circ} \mathrm{C}$ 오븐에 서 24시간 건조 시킨다. 이 과정이 끝나면 설폰화 실리 카 촉매가 만들어진다. Fig 4.는 실리카와 설폰화 실리 카 촉매의 분자 구조이다.

\section{3 단당류 생성 실험}

앞서 2.2 에서 만들어진 산촉매를 이용하여 커피 분자 를 분해하기 위해서는 여러 과정이 필요하다. 먼저 커피 와 산촉매가 충분히 반응 할 수 있게, 볼밀기(Ball-Mill) 를 이용한다. 커피찌꺼기 $150 \mathrm{mg}$ 과 산촉매 $150 \mathrm{mg}$ 을 볼 밀기를 통해 혼합시킨 다음, 얻어낸 무게에 맞추어 증류 수를 첨가한다. 볼밀 과정 중 혼합물의 손실이 있기 때 문에, 무게를 재고 난 후 증류수를 넣어줘야 한다. 혼합 물과 증류수의 비율은 20:1로 넣어준다. 이렇게 만들어 진 혼합물을 수열합성기에 넣어 $150^{\circ} \mathrm{C}$ 오븐에서 12 시간 반응시킨 후 냉각이 끝나면 여과장치를 통해 여과시킨 다. 여과가 끝나면 앞선 실험들과 마찬가지로 $80^{\circ} \mathrm{C}$ 오븐 에서 24시간 건조 시킨다. 수열합성을 통한 가수분해에 대한 그림은 Fig 5에 나타내었다. 


\section{3. 분석}

\subsection{Structural Analysis}

Fig 6은 실리카와 설폰화 실리카에 대한 X-ray Diffraction (XRD)이다. 두 XRD 그래프를 보았을 때 실리카와 설폰화 실리카 사이에 큰 차이가 보이지 않기 때문에 설폰화로 인한 결정구조의 변화는 없는 것을 알 수 있다. 두 그래프 모두 공통적으로 $20 \sim 25$ 도 지역에 서 넓은 면적의 피크가 나타나고, 이후 추가적인 영역에 서는 결정 평면이 나타나지 않는다. JCPDS 카드의 실 리카 고유 식별 번호 (No.47-0715)를 사용하여 비정질 구조의 형태를 가진 입자들이 형성된 것을 알 수 있다.

\subsection{Morphology analysis}

Fig 7 (a)는 플라즈마를 이용하여 제조한 실리카, (b)

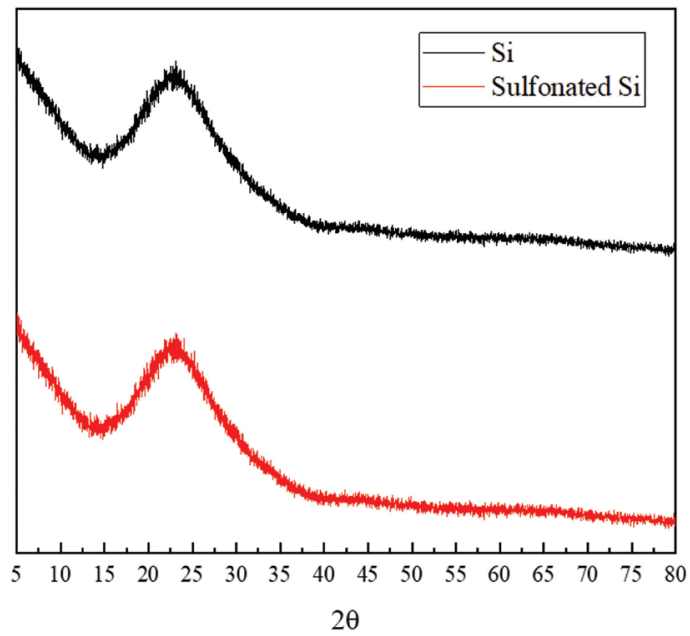

Fig 6. 실리카와 설폰화 실리카의 XRD 데이터

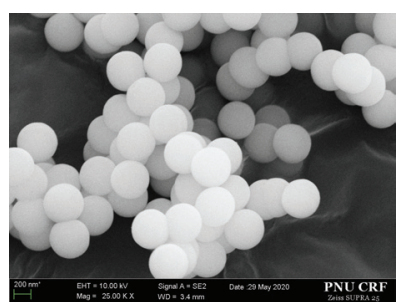

(a) 플라즈마를 이용하여 생성된 실리카

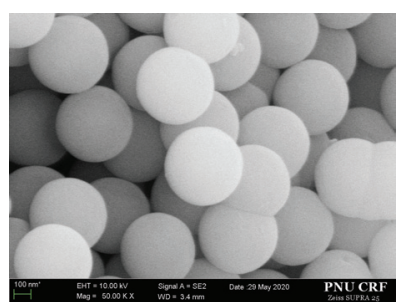

(b) 졸-겔법을 이용하여 생성된 실리카

는 졸-겔을 이용하여 제조한 실리카, (c), (d)는 설폰화 실리카에 대한 SEM 사진이다. SEM 사진에서 XRD 데 이터와 마찬가지로 설폰화 과정 전후에 큰 차이가 보 이지 않는다. 또한 졸-겔법으로 생성된 실리카와 플라 즈마를 이용한 실리카 역시 육안으로는 큰 차이를 보 이지 않는다. 생성된 실리카의 크기를 보면 약 500 $600 \mathrm{~nm}$ 로 나노 크기의 구형 입자가 형성된 것을 알 수 있으며, 균질한 형태의 입자가 형성되었다. FIg 8와 Table 2은 실리카에 대한 EDS로 실리카가 잘 생성되었 는지 알아보았다. 겉보기 농도는 $\mathrm{Si}: \mathrm{O}$ 의 비율이 약 1 $: 2$ 로 실리카의 분자식인 $\mathrm{SiO}_{2}$ 를 만족하였다.

\subsection{Textural Properties}

$\mathrm{SEM}$ 사진만으로는 실리카의 입자 크기 정도만 확인 이 가능하고, 기공의 크기와 기공의 부피 등 촉매 성능 을 판단하기는 어렵다. 그렇기에 Brunauer-EmmettTeller (BET) 분석을 통하여 촉매 성능을 판단하기 위 한 기준들을 분석해 보았다. BET 데이터는 Fig 8로 나 타내었다. (a)와 (b)는 플라즈마로 생성된 실리카를, (c) 와 (d)는 졸-겔법으로 생성된 실리카이다. 표면적은 각 각 5.99에서 6.44로 근소하게 증가했다. (b)와 (d) 그래 프를 비교해 보면 플라즈마로 생성된 실리카는 $10 \mathrm{~nm}$ 의 기공이 많이 생성되었고, 졸-겔법으로 생성된 실리카는

Table 2. EDS 분석 표

\begin{tabular}{c|c|c|c|c|c}
\hline Element & Line Type & $\begin{array}{c}\text { Apparent } \\
\text { Concentration }\end{array}$ & k Ratio & Wt\% & $\begin{array}{c}\text { Wt\% } \\
\text { Sigma }\end{array}$ \\
\hline $\mathrm{O}$ & K series & 51.22 & 0.1724 & 61.80 & 0.06 \\
\hline $\mathrm{Si}$ & K series & 29.59 & 0.2345 & 38.20 & 0.06 \\
\hline Total: & & & & 100.0 & \\
\hline
\end{tabular}

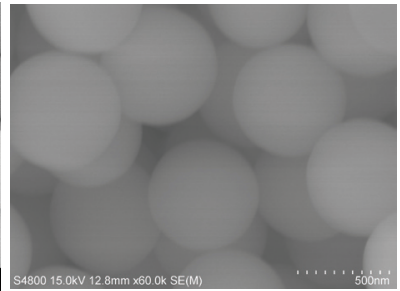

(C) 설폰화 후 실리카

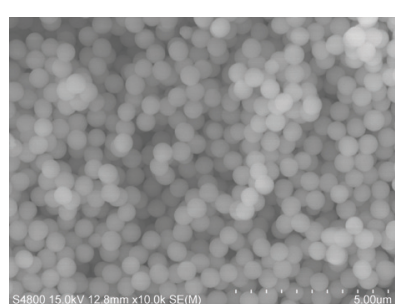

(d) 설폰화 후 실리카

Fig 7. SEM 
$10 \mathrm{~nm}$ 보다 작은 기공이 생성되었다. 이로 인해 표면적 의 변화가 발생하였고 이는 촉매 성능에서의 차이가 발 생할 것임을 예상할 수있다.

\subsection{Total Acid and sulfonic density (적정)}

적정이란 특정 화학종으 lshdeh를 결정하기 위해 사 용하는 정량 분석법의 일종이다. 이 실험에서 사용된 적 정법은 산염기 적정을 사용하여 산과 염기의 농도를 알 고자 할 때 정확한 농도를 알고 있는 염기나 산의 표 준 용액으로 중화반응을 일으켜 그 농도를 결정하는 방

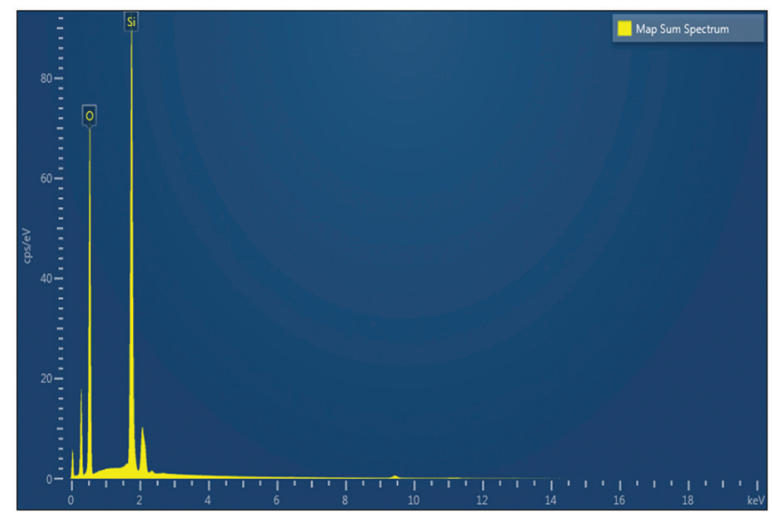

Fig 8. 플라즈마로 이용하여 생성된 실리카의 EDS
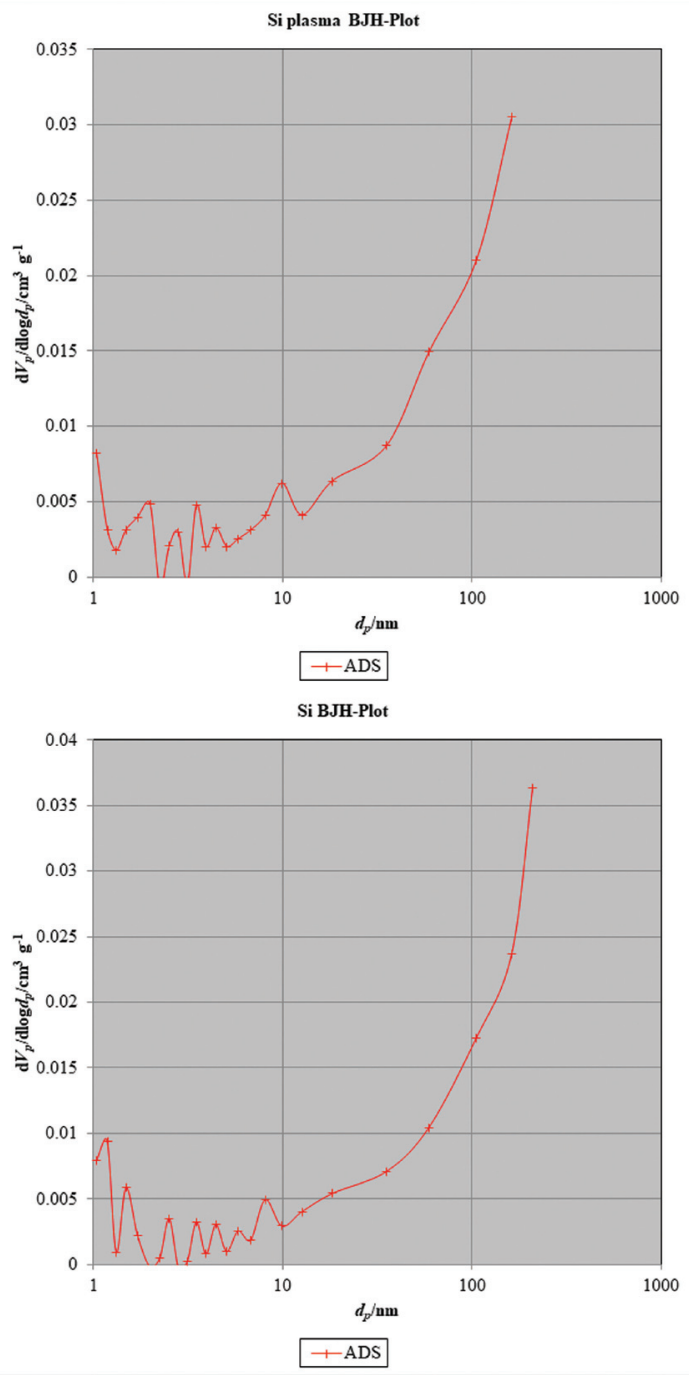

(b) 플라즈마를 이용한 실리카의 BET 데이터(BJH-plot)

(d) 졸겔법을 이용한 실리카의 BET 데이터(BJH-plot)

Fig 9. (a) 플라즈마를 이용한 실리카의 BET 데이터(desorption isotherm) (c) 졸겔법을 이용한 실리카의 BET 데이터(desorption isotherm) 
Table 3. 적정법을 통한 촉매의 산 밀도

\begin{tabular}{c|c|c}
\hline & Total acid density & $\mathrm{SO}_{3} \mathrm{H}$ acid density \\
\hline $\begin{array}{c}\text { 졸-겔법 설폰화 } \\
\text { 실리카 }\end{array}$ & $5.46 \pm 0.2$ & $0.7 \pm 0.1$ \\
\hline $\begin{array}{c}\text { 플라즈마 설폰화 } \\
\text { 실리카 }\end{array}$ & $5.48 \pm 0.2$ & $0.86 \pm 0.2$ \\
\hline
\end{tabular}

법을 사용하였다. 전체 산밀도 (Total acid density)는 $\mathrm{SO}_{3} \mathrm{H}$ 작용기의 밀도와 $\mathrm{COOH}$ 작용기의 밀도, $\mathrm{OH}$ 작 용기의 밀도로 표현이 가능하다. $\mathrm{NaOH} 0.01 \mathrm{M} 30 \mathrm{ml}$ 를 이용하여 촉매의 산성작용기를 $\mathrm{NaOH}$ 와 반응시킨 후 반 응한 작용기의 양을 구하기 위해 $\mathrm{HCl}$ 을 사용해 적정을 하였다. 첨가한 $\mathrm{HCl}$ 의 양을 $\mathrm{x}$ 라고 하면, 식은 다음과 같 다. 여기서 $\mathrm{x}$ 는 페놀프탈레인 용액의 색 변화를 통해 구 할 수 있고, $\mathrm{A}$ 는 적정 시 사용한 촉매의 양이다.

\section{Total acid density $=$}

$$
\frac{(0.01 \mathrm{MNaOH}) \times(30 \mathrm{ml})-(0.01 \mathrm{MHCl}) \times(x \mathrm{ml})}{(\mathrm{A}) \mathrm{g}}[\mathrm{mol} / \mathrm{g}]
$$

$\mathrm{SO}_{3} \mathrm{H}$ 의 밀도는 $\mathrm{NaCl} 0.01 \mathrm{M} 30 \mathrm{ml}$ 를 이용한다. 촉매 의 $\mathrm{OH}$ 작용기와 $\mathrm{COOH}$ 작용기는 $\mathrm{SO}_{3} \mathrm{H}$ 작용기에 비해 결합이 약하다. $\mathrm{NaCl}$ 용액은 $\mathrm{SO}_{3} \mathrm{H}$ 작용기와만 반응하 기 때문에 $\mathrm{SO}_{3} \mathrm{H}$ 작용기의 밀도를 구할 수 있다. 생성된 $\mathrm{HCl}$ 의 양을 구하기 위해 $\mathrm{NaOH}$ 를 이용하여 적정을 진 행한다. 첨가한 $\mathrm{NaOH}$ 의 양을 $\mathrm{y}$ 라고 하면 식은 다음과 같다.

$\mathrm{SO}_{3} \mathrm{H}$ acid density $=$

$$
\frac{(0.01 M N a O H) \times(y m l)}{(A) g}[\mathrm{~mol} / \mathrm{g}]
$$

위의 식으로 구하였을 때, 산밀도를 Table 3. 으로 나 타내었다.

Total acid density는 졸-겔법과 플라즈마 공법을 이 용한 촉매 근소한 차이가 났지만, $\mathrm{SO}_{3} \mathrm{H}$ 의 경우 $0.1 \mathrm{~mol} /$ $\mathrm{g}$ 으로 유의미한 차이가 났다. 앞서 설명한 $\mathrm{BET}$ 데이터 에서의 표면적 크기 차이가 $\mathrm{SO}_{3} \mathrm{H}$ 결합의 차이의 원인이 라고 보여진다.

\subsection{Catalytic performance}

HPLC (High-Performance Liquid Chromatography)라는 분석법은 고정상과 시료 및 이 동상과의 상호작용으로 혼합물을 단일성분으로 분리시 켜 분석하는 방법이다. 액체 크로마토그래피는 기체 크 로마토그래피와 다르게 분석할 수 있는 분자량의 제한 이 없기 때문에 휘발성이 없는 시료를 분석할 수 있을 뿐 아니라 분자량이 큰 시료도 분석이 가능하다. 이 실 험에서는 촉매를 통해 분해된 커피가 어떠한 성분으로 분해가 되었는지 알기 위해서 이 분석법을 사용하였다.

Fig 10은 HPLC 분석을 통해 글루코스, 자일로스에 대한 피크를 나타낸 것이다. HPLC 분석을 통해 얻은 성 분으로는 글루코스, 자일로스, 글리세롤, 아세트산등이 있다. 이 때 피크를 통해 얼마만큼의 성분을 생성했는지 알기 위해서 다음과 같은 식을 통해 구할 수 있다.

Concentration of $A[\mathrm{mg} / \mathrm{mL}] \times$ water $[m L] \times$ Xcarbon one molecular Aatomicmass $[\mathrm{g} / \mathrm{mol}]$

이 때 $\mathrm{A}$ 의 농도는 가수분해가 끝난 후 HPLC를 통해 구한 농도이고, 물은 가수분해 당시 넣어주었던 증류수 의 양이다. 위 식을 통해 각 성분의 탄소 몰농도를 구한 후 커피에서 얼마 만큼 변환이 되었는지 구하기 위해서 는 아래 식을 이용한다.

$$
\text { Conversion of } \mathrm{C}=\frac{\text { Mol. } \operatorname{Cof} A}{\text { Mol. Cof coffee }}
$$

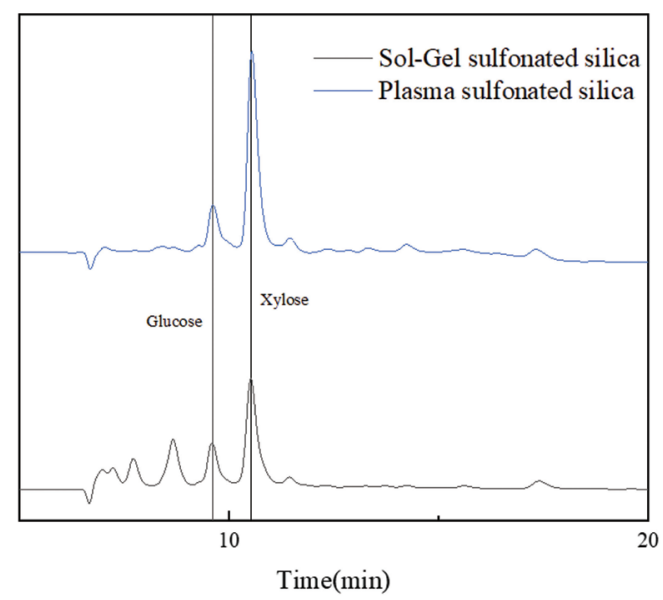

Fig 10. HPLC 데이터 
Table 4. 설폰화 실리카를 이용하여 커피 분해 결과

\begin{tabular}{c|c|c|c}
\hline Sample & $\begin{array}{c}\text { Xylose } \\
\text { conversion }\end{array}$ & Selectivity & Total yield \\
\hline $\begin{array}{c}\text { 졸-겔 설폰화 실 } \\
\text { 리카 }\end{array}$ & $10.7 \%$ & $69 \%$ & 15.5 \\
\hline $\begin{array}{c}\text { 플라즈마 } \\
\text { 설폰화 실리카 }\end{array}$ & $16.02 \%$ & $73 \%$ & 22.2 \\
\hline
\end{tabular}

이를 통해 자일로스의 전환율과, 자일로스의 선택 률(selectivity) 그리고 총 전환율을 계산하였다. 이는 Table 4로 나타내었다. 그 결과 자일로스의 선택률과 전환율 모두 상승하였으며, 전체 수율 역시 증가하였다.

\section{4. 결론}

결론적으로, 플라즈마를 통한 실리카는 촉매로서의 새로운 가능성을 보여주었다. 동일한 시간 동안 실험을 진행하여 얻은 양을 보면, 플라즈마 공법의 양이 더 많 았다. SEM의 사진으로 보았을 경우 실리카의 입자 크 기는 큰 차이가 나지 않았지만, $\mathrm{BET}$ 데이터를 보면 플 라즈마를 사용할 경우 기공의 크기가 커짐으로 인해 비 표면적이 차이가 발생함 알 수 있었다. 비표면적의 차 이는 그렇게 큰 차이가 나지 않았지만, 촉매의 성능으 로 보았을 때 전환율과 선택율은 졸-겔법을 사용하였을 때 $10.7 \%, 69 \%$ 인데 반해, 플라즈마공법을 사용할 경우 $16.2 \%$ 와 $73 \%$ 로 각각 약 $6 \% .4 \%$ 의 증가함을 알 수 있었 다. 단순 실험적 수치로 본다면 매우 높은 성능의 향상 은 아니지만, 산업 규모의 대규모 공정으로 생각할 경우 충분히 가치 있는 결과라고 생각된다. 실리카의 입자 크 기는 TEOS와 $\mathrm{NH}_{4} \mathrm{OH}$ 의 비율에 따라 크게 달라지므로 이를 좀 더 최적화시킨다면 더 작은 입자 크기의 실리카 를 얻을 수 있을 것으로 예상된다. 플라즈마를 통한 기 공 생성의 경우 여기 플라즈마의 세기에 따라 영향을 받 기 때문에 이 역시도 최적화 과정이 아직 필요하다고 생 각된다. 차후 최적화에 성공한다면, 더 높은 성능의 실 리카 산촉매를 생성 가능하여 환경 문제 해결에 기여할 수 있을 것으로 생각된다.
사사

This work is supported by the National Research Foundation in Korea (NRF)," 한구연구재단 기본연구 (2018R1D1A1B07048518)".

\section{REFERENCES}

1. C. S. Ha, H. D. Park, and C. W. Frank, Chem. Mater., 12,839 (2000).

2. 임영웅, 졸-갤 재료에 대한 기술과 응용에 대하여, 한국 과학기술정보연구원

3. Ismail A.M. Ibrahim, Amina Zikry, Mohamed A. Sharaf, Chemistry Department, Faculty of science, Helwan University, Egypt. J. Am. Sci., 2010;6(11):985:989. (ISSN: 1545-1003).

4. S. V. de Vyver, L. Peng, J. Geboers, H. Schepers, F. Clippel, C. J. Gommes, B. Goderis, P. A. Jacobs, B. F. Sels. Sulfonated silica/carbon nanocomposites as novel catalysts for hydrolysis of cellulose to glucose. Green Chem., 12 (2010) 1560-1563.

5. Y. Kato, Y. Sekine. One Pot Direct Catalytic Conversion of Cellulose to Hydrocarbon by Decarbonation Using $\mathrm{Pt} / \mathrm{H}$-beta Zeolite Catalyst at Low Temperature. Catal Lett., 143 (2013) 418-423.

6. J. Li, Helena S. M. P. Soares, Jacob A.Moulijn and M. Makkee. Simultaneous hydrolysis and hydrogenation of cellobiose to sorbitol in molten salt hydrate media. Catal. Sci. Technol., 3 (2013) 1565-1572.

7. P. Wolf, C. Hammond, S. Conrad. I. Hermans. Postsynthetic preparation of Sn-, Ti- and Zr-beta: a facile route to water tolerant, highly active Lewis acidic zeolites, Dalton Trans., 43 (2014) 4514-4519.

8. Maschmeyer, T., Rey, F., Sankar, G. et al. Heterogeneous catalysts obtained by grafting metallocene complexes onto mesoporous silica. Nature 378, 159-162 (1995). https://doi.org/10.1038/378159a

9. 한용희, 최상진, 임준현, 장영기, 이종철 (2017). 커피 로스팅 시 배출되는 대기오염물질 배출량 추정. 한국대 기환경학회 학술대회논문집, 168-168 
10. Anil Lachke. Biofuel fromD-xylose - The second most abundant sugar. Resonance volume 7, pages5058(2002)

11. 오영제, 김승현 (1995). Sol-Gel 반응 공정의 원리, 평 가 및 응용. 세라키스트, 10(2), 141-151

\section{Prof. (Helena) Oi Lun Li}

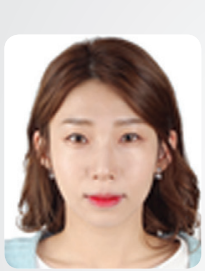

- Oi Lun $\mathrm{Li}$ received her $\mathrm{Ph}, \mathrm{D}$ degree at McMaster University, Canada in 2010. She was an assistant professor in Nagoya University until 2016, and currently promoted as an associate professor at the School of Materials Science and Engineering of Pusan National University. Her research interests include plasma chemistry and novel synthesis method for catalytic materials for renewable energy including hydrogen production, fuel cell, metal-air battery and biomass conversion to value-added products

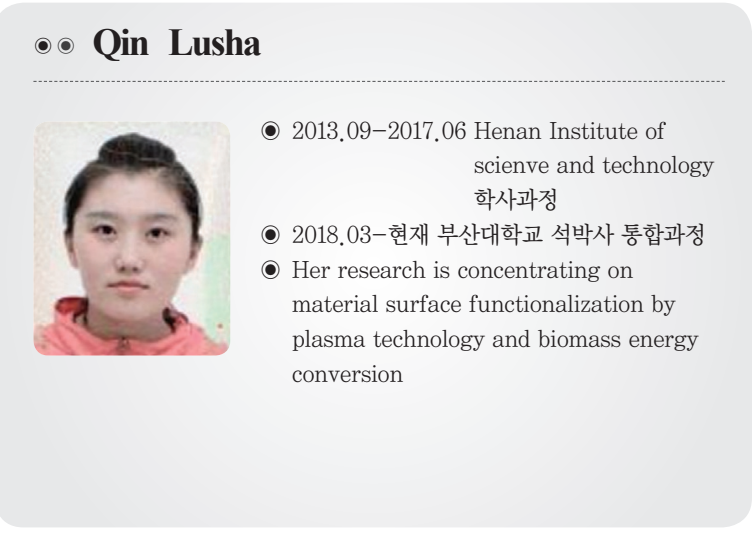

12. S. Hu, T. J. Smith, W.Lou, M. Zong. Efficient Hydrolysis of Cellulose over a Novel SucraloseDerived Solid Acid with Cellulose-Binding and Catalytic Sites. Agric. Food Chem., 62 (2014) 19051911.

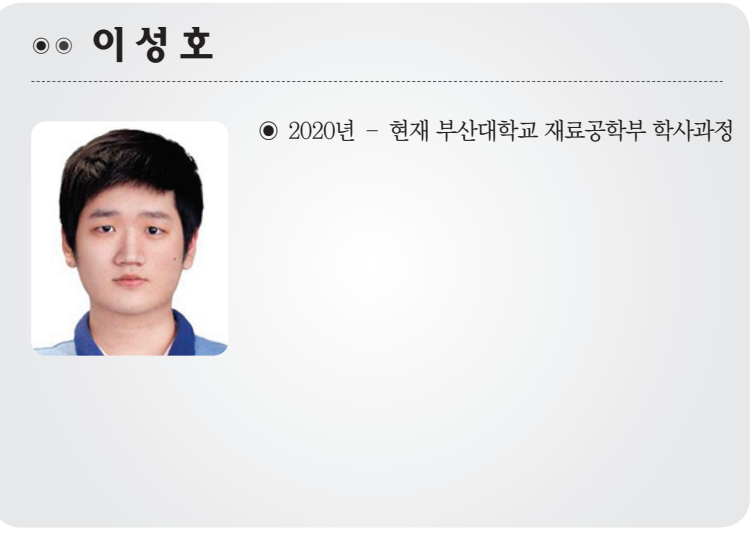

